\title{
A renewed path for skilling in IT/ITeS sector for transition to the new normal
}

\author{
${ }^{1}$ Mini Sherino, ${ }^{2}$ Dr. N M K Bhatta \\ ${ }^{1}(\mathrm{PhD}$ Scholar, Xavier Institute of Management \& Entrepreneurship \\ (A recognized Research Centre of University of Mysore) \\ ${ }^{2}$ (Dean, Xavier Institute of Management \& Entrepreneurship \\ (A recognized Research Centre of University of Mysore)
}

\section{ABSTRACT}

Every drawdown is an indication to a new beginning - an exploration of a renewed trajectory to meet our goal, the sooner it is demarcated, the better the adaptability and success rate. A compulsive disruption from usual ways of working to a forced new normal is what the IT/ITeS skills ecosystem in India is called to embrace as the challenge of the era. An examination of the evolving IT/ITeS skills ecosystem in India, identifying of the skill skewed areas where incremental demand for talent needs to generate through the existing skilling, reskilling and upskilling programs and investing more in those areas would serve the purpose of the Skill India movement launched way back in 2015. The research paper expounds on the need for a revival of the system of IT Skilling adhered to under the Skill India movement of India, in order to prove more beneficial to help employability of the incumbents. Based on a survey of 367 graduates of IT Skill courses, the study concludes by enumerating those specific IT skills or key thrust areas in skilling that need focus and adaptability of Training institutions to incorporate these key skills and a renewed skilling path to the PMKVY skill training so as to emerge successful in the era of the New Normal.

Key Words: IT/ITeS Skills ecosystem, Skill skewed, Skilling, reskilling, Upskilling

Article Received: 18 October 2020, Revised: 3 November 2020, Accepted: 24 December 2020

\section{INTRODUCTION}

The world today is on the lookout for alternate markets, production systems and models that are technology adept, agile in customer responsiveness and resilient to disruption or uncertainties. While governments world over are engaged in combing strategies to thwart COVID-19 and equip their economies to thrive ahead amidst the drawdown, fund allocation to priority areas like healthcare, manufacturing, construction, agriculture, IT enabled services would remain key focus areas. Ever since the inception of the Skill India movement in the early 2015 , this system has evolved into a vibrant integrated mission encompassing both Academic and vocational skill training courses in its stride. A compulsive disruption from their usual ways of working to a forced new normal is what the IT/ITeS skills ecosystem in India is called to embrace as the challenge of the era. Official reports and statistics of dwindling funds allocation for the ambitious PMKVY programs tend to bother the pace of the program's success. The government and bureaucracy are busy charting out newer ways of moving ahead with its skill development policies. More funds need to be siphoned to stimulate growth of emerging skillsets through these ambitious programs. Insights from the latest Skill India report 2020 and a few studies among different stakeholders conducted has proven a new turn to the otherwise lacklustre skill India program. This paper intends to throw light upon the significance of the Skills ecosystem in India, the objectives of the Skill India movement, those key sector areas that have assumed importance in the wake of the present uncertainties in India and the kind of alternative routes in skilling, upskilling and reskilling that the country would need to traverse in order to remain triumphant in the domain of skills.

Key Words: IT/ITeS Skills ecosystem, Skill skewed, Skilling, reskilling, Upskilling

\section{LITERATURE REVIEW}

The Skill India movement

Recognizing the need for a more organized system for promotion of Skill Development and Entrepreneurship in the country among the youth, a separate Department for Skill Development to coordinate all concerned stakeholders was given effect to by the Government of India in July 2014. This got upgraded into the Ministry of Skill Development \& Entrepreneurship in November 2014, with additional skilling initiatives extended to Information technology, Industrial training Institutes, for Science \& technology, Small business development and even for appropriate mapping to academic equivalent skillsets. (Annual report MSDE, 2017-18) The improved outreach and outcomes of the initiative 
were emboldened through the official launch of Skill India movement by the government in 2015. This has also helped in increased awareness, acceptance and participation of the youth of the country, in these meaningful livelihood improvement programs. Noteworthy among the Ministry's functions is its Yearly Incremental human resource requirement (both Sectoral and Geographical spread) mapping identified across 24 or more sectors of the economy.
(Environment Scan report NSDC, 2016). An analysis of these studies has led to development of Skills Action plan (SAP) for tackling specific skill needs of each sector and state.

The hitherto fragmented programs (on skill development) of several ministries were brought within the collaborative framework of Skill India movement with the MSDE as the nodal functionary in 2015. (Figure 1 is an illustration of the entire framework)

\section{FIGURE 1}

\section{SKILLS DEVELOPMENT FRAMEWORK CONSTITUTED UNDER THE SKILLS INDIA PROGRAM OF 2015}

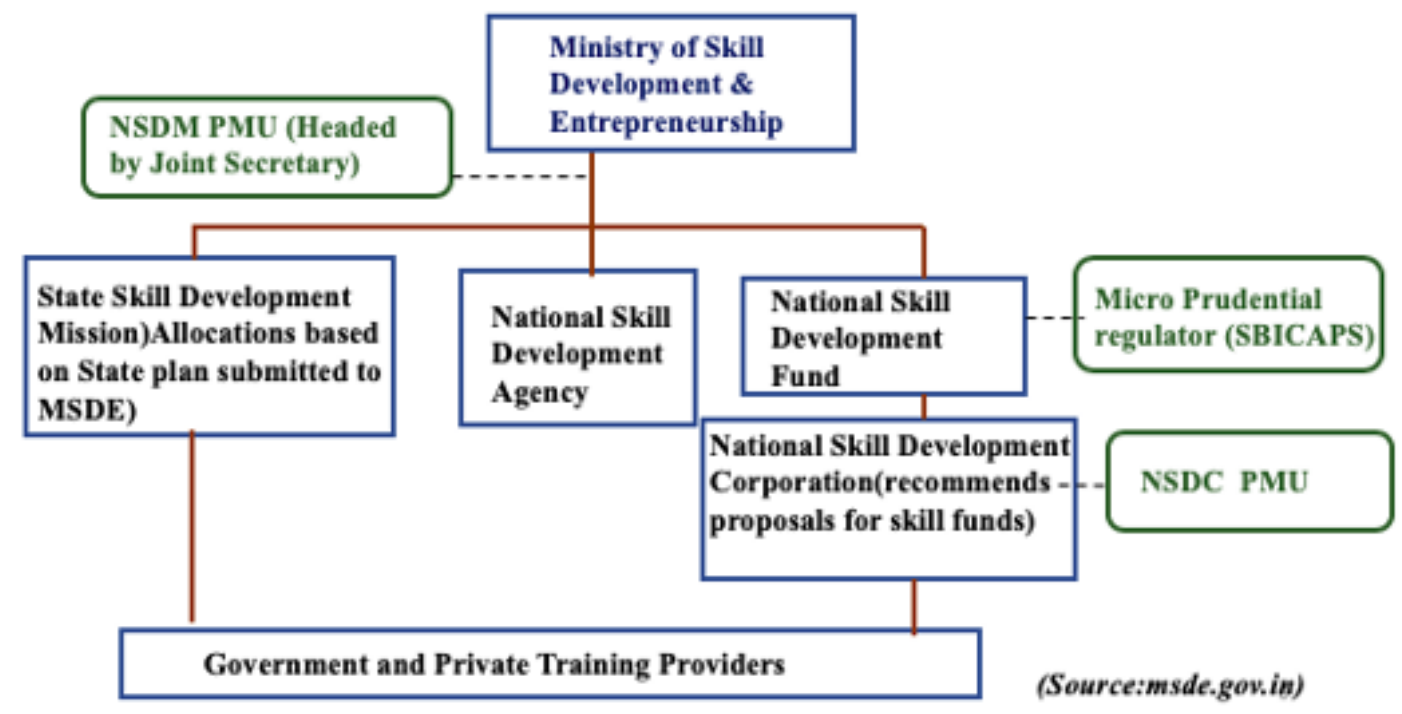

The Skills ecosystem or landscape in India

The Skills ecosystem in India has been a significant milestone in the development of newer models of Education in India with a focus on employability. Ever since the inception of the Skill India movement in the early 2015, this system has scaled into a vibrant integrated mission encompassing both Academic and vocational skill training courses in its umbrella (Mehrotra, 2016). It has had its tremendous outreach into the rural and urban sections of Indian population and has tumulted a twist to better mobility of skills nationwide and to employment pockets abroad.

New Programmes for skill upgrade under the Skill India Campaign 2015

\section{Pradhan Mantri Kaushal Vikas Yojana (PMKVY)}

2. Pradhan Mantri Kaushal Kendras (PMKK)

3. Sankalp ( Skills acquisition and knowledge awareness for livelihood promotion )

4. Skill Strengthening for Industrial value enhancement (STRIVE) scheme

5. UDAAN (For UT of J\&K only)

6. Polytechnics submission transfer
7. Vocational Educational Institutions under Universities

(National Skill Development Mission,

2015)

A vast ecosystem, that has been growing in size and over the years, adding into its flow several streams of skill sets that have extended interest areas from Academics, Industrial training and Research studies. An array of innovative new skills facilitating the youth for 
better employability and financial benefits has been accumulating under 52 different sectors of Indian economy over the years as a result of this system (NCO, 2015). The initiation of the Ministry of Skills Development \& Entrepreneurship (MSDE) in 2015 has electrified the growth of Skill Development training in India from its nascent state to what has come out as it appears in its structure today. While there are further improvements being thought of in the nature of merger of the current streams of Academic courses with the Vocational educational structure, more awareness and acceptance of skill development among the workforce would be a long term desirable task the Government and Education experts would need to prioritise to accomplish in the upcoming years to envision development for the country. (Mehrotra, 2016)

A National Skills Qualification framework (NSQF) has been set up by the National Skills Development Corporation of India (a nodal agency of MSDE) that organizes varied skills (pertaining to distinct job roles The pace of this growth is expected to accelerate in the upcoming years as we emerge from the pandemic.

FIGURE 2 in the industry) into four grades of I, II, III and IV. Job roles or occupations are enlisted with their specific skills sets aligned to the NSQF which tallies with international standards of employability to jobs of such kind (National Policy for Skill Development and Entrepreneurship, 2015). This standardization in skills has been assured on skills taught by the varied Skill Development institutes of the country, that have emerged as a result of Skills India movement in 2015. (National Skill Development Mission, 2015)

Why IT/ITeS skills assume more significance in the upcoming years

If there were ever a time in history to ensure that Development initiatives drive optimum results to the nation's economic growth, it is now.

Economic Survey of India, 2018-19 has highlighted the significance of the IT/ITeS sector in contributing to the GDP of the country.

\section{IT/ITeS sector contribution to India's GDP}

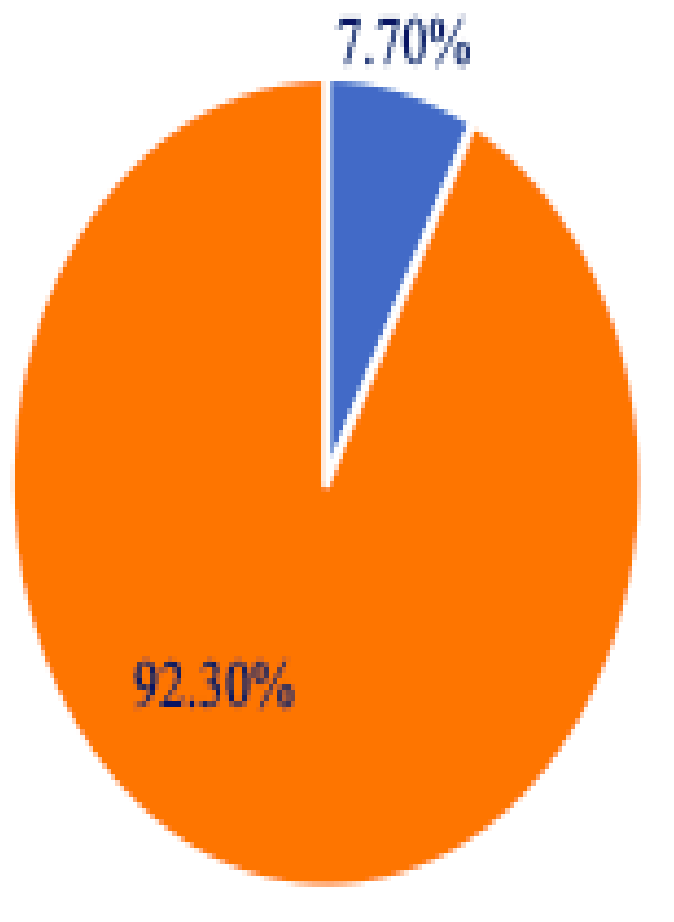

- IT/TTeS sector

n Others

(Source: Economic Survey of India 2018-19; National Information Technology Policy 2012) 
By understanding the impeccable potential of technology in a remotely connected world, importance of IT Skilled workforce and the need of building up 'Employability skills' among the people around this domain proved the need of the hour. The spree in reports on post pandemic analytics studies have indicated emergence of a world controlled by a Digitized economy. A Digitized economy would need a workforce equipped to meet its demand, by having the right kind of skills to enhance consumer spend and business continuity in the future. (Singhal \& Sneader, 2020)

Analytics, Machine learning, Data Science have been taking top seats among most demanded for skills in IT/ITeS sector today. (NASSCOM B2B, 2019)

The Indian economy has been able to maintain a growth rate of $8 \%$ during the last decade (Economic Survey reports), The contribution of IT industry as a catalyst for growth for the country cannot be undermined. - this sector being an employment hub offering employment opportunities to over $2.8 \mathrm{~m}$ skilled people. (National Information Technology Policy, 2012). This Sector has been considered as a major driver in directing the country's developmental progress through the Skill India movement. There is more room and much more that needs to be done for skilling, reskilling and upskilling workforce to increase productivity and resourcefulness of the massive demographic dividend in this domain.

What do we mean by being Skill skewed?

Any distribution that is asymmetrical and is biased to one end is called a skewed distribution. A similar kind FIGURE 3.

\section{SKILL SKEWED IT/ITeS SECTOR IN KARNATAKA}

of skewedness is observed when it comes to skill training types for the larger workforce. In the Indian context, choice of studies is highly dependent on the employability potential inherent in them. As a result, there is a skewedness towards professionalism - towards Engineering and Management academic curriculum. Any kind of shift from these domains to a newer stream, is only met with skepticism and is relatively lower in numbers. (Khare, 2014)

Again, skewedness in skills is indicated by the severe problem of 'underemployment' which protrudes uglier than unemployment in India. Though the demand of IT/ITeS skilled workforce is quite high in India, the availability of relevant skills appropriate to fill up the job roles would need to be created so as to redress job loss issues. More so in this line of studies, has emerged the concept of 'employability skills' - the need for resources with a combination of formal education, technical skills, soft skills and team working skills for job roles. (Bhattacharya, 2017). If Skill India movement is to be successful in attaining its goal of 300 million skilled workforce by 2030, it would need to redirect its efforts into the new path to efficiently drive employability.

Taking a look at the figure below, one would be able to understand how from among a 28 million of Workforce population, it is just 0.8 million who constitute the IT sector workforce. This 0.8 million which is $\sim 2.8 \%$ of Workforce population effectively contributes to the 42\% State revenues yearly. (Karnataka Skills gap report, 2013). This being the compelling reason why this paper delves more into understanding the skill training initiatives in the IT sector in Karnata 


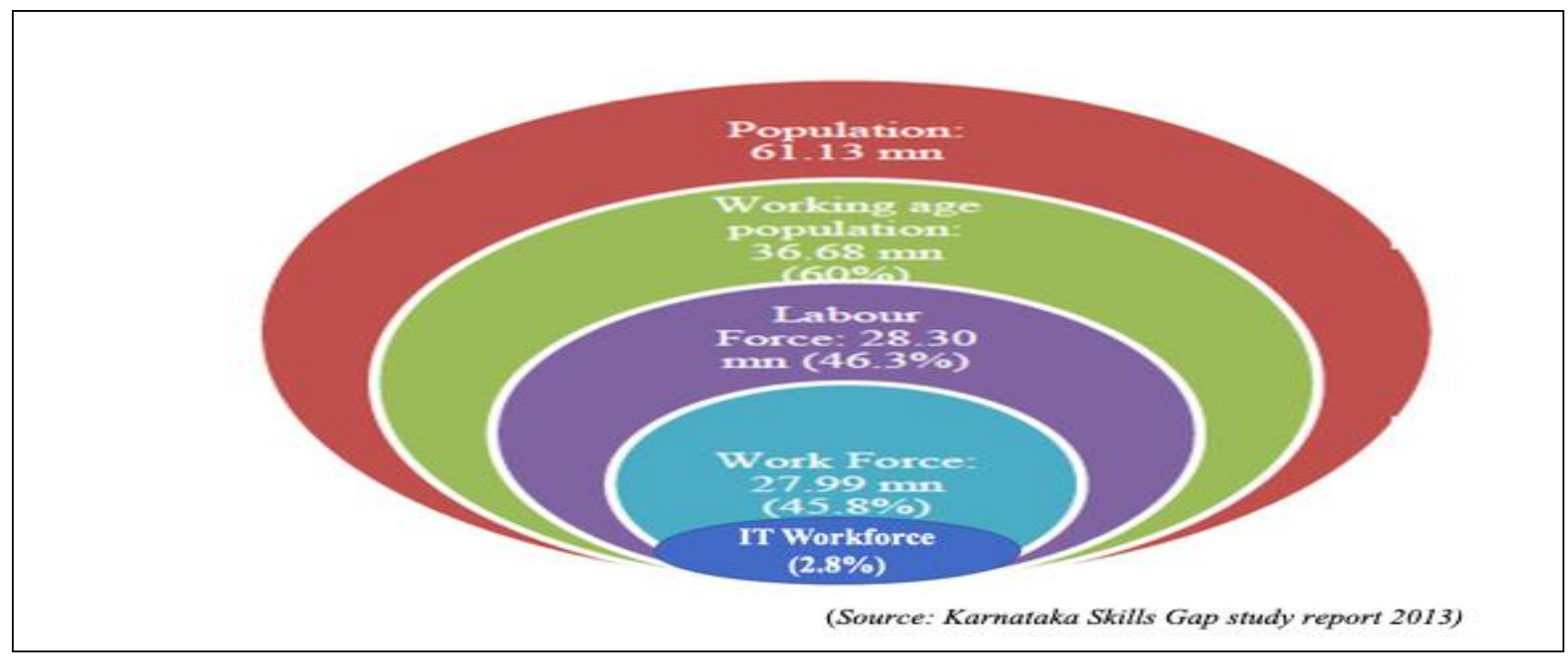

Having touched upon the significance of the Skills ecosystem in India, the objectives of the Skill India movement, we take you through those key sector areas that have assumed importance in the wake of the present uncertainties in India and the kind of alternative routes in skilling, upskilling and reskilling that the country would need to traverse in order to remain upbeat and essential.

The World Economic Forum has predicted a rapid disruption in the workplace resulting in the creation of 133 new roles in place of 75 million that would be removed from industry owing to automation and unprecedented move to a digitized economy. Off late studies have proven that Data Science and Analytics holds tremendous scope in shaping future course of businesses. Many of the skill upgrades demanded by employers worldwide point to the drastic changes in conventional Analytics \& Business Intelligence jobs. Thus, a shift towards the following job roles.

The ambitious and regularly talked about PMKVY programs are of 3 types

\begin{tabular}{|l|}
\hline $\begin{array}{l}\text { SHORT TERM TRAININGS } \\
(\mathrm{STT})\end{array}$ \\
\hline RECOGNITION OF PRIOR \\
LEARNING (RPL) \\
\hline SPECIAL PROJECTS (SP) \\
\hline
\end{tabular}

NON PMKVY programs span over all IT/ITeS skills training delivered through other agencies like UGC, ITI,
1. Robotics Process Automation jobs

2. Artificial Intelligence and Machine Learning jobs

3. Applications Design experts (that enable operational costs reduction through elimination of repetitive tasks or activities.)

4. Coding experts

5. Data Scientists (data wrangling, mining, visualization, analytics)

6. Cloud Computing technical experts

7. Cyber Security experts

(NASSCOM B2B, 2019)

To discern on the kinds of alternative routes in skilling, upskilling and reskilling that the country would need to thread on to, an examination of the present situation seems essential.

Programs in IT/ITeS skill development currently are provided in two major categories., viz.,

\section{PMKVY \\ 2. NON PMKVY programs}

General academic institutions aligned to the industry and online mode.

While budgetary allocations yearly have seen a dwindling effect in the case of the PMKVY projects, the NON PMKVY fund route is undoubtedly more agile and effective to help serve objectives of the Skill India movement.

Since there are hardly any studies to vouchsafe on/evaluate how successful the NON PMKVY route to Skills training could be, this paper undertakes a ground level evaluative analysis on their effectiveness and 
importance of encouraging more IT skilling through the Non PMKVY mode.

\section{Rationale of the Study:}

There are a number of computer science graduates in India, who are unemployed. But the IT/ITeS sector in India has a huge demand for IT skilled professionals. This shows that the skills that are provided are inadequate or trained professionals need reskilling in order to support the demand in the job market. There is an urgent need to skill available manpower on these skills, that are considered emerging and significant in today's industry. This will help in increased employment in the IT/ITes sector, which contributes to $7.8 \%$ of GDP growth of the country. The rationale of the study will help identify the types of skilling that need to be promoted in the IT sector and what type of models to be used to improve productivity of its trained professionals.

The Objectives of this study are summarized below:

1. Exploratory study on the curriculum and content of IT/ITeS skill training programs (technical and soft skills) under Skill India movement (PMKVY and Non PMKVY)

2. Evaluation on the effectiveness of these programs in increasing employability potential of the massive workforce in India

Hypotheses derived therefrom, that have directed the course of this study are:

H1.0 IT/ITeS training programs under Skill India movement do not help in bridging the gap in employability in India

H2.0. There is no difference in the effectiveness of the various skill training programs under Skill India movement (PMKVY and Non PMKVY).
A Quantitative investigation based on survey as the measurement instrument was devised to be floated among two kinds of respondents - Trainers and Trainees of Skill India programs. The Questionnaire prepared with a majority of structured questions (30 in number) on a five-point Likert scale, also included a few Open-ended questions. American Institute of Researchers skillset scale of 2016 was the major highlight of these questions, with improvisation based on Industrial and academic expert advice.

Two evaluative studies were undertaken parallelly on Trainers and on trainees or graduates who had benefitted out of these IT/ITeS training programs in Urban and Rural districts of Bangalore. These studies were initiated to understand the outreach of the IT skill programs among the masses, of which were more preferred, which were considered more beneficial in the long term (in terms of employability potential and other allied advantages). The other objectives that were intented to be achieved through this study was identifying those skillsets or courses that had a higher propensity for upskilling and recommend the same for further advancement by increased funding support from administration. For this the perspective of trainers was required to be analyzed and rated with general opinion from IT Industry.

Descriptive statistical graphs and charts, along with Perceptual mapping were the techniques used for the purpose of analyzing the results of the studies.

The first study among (356) graduates of IT/ITeS Skill India training courses (both PMKVY and Non PMKVY) in Bangalore. Of the responses received 25\% were of PMKVY trainees and the rest of NON PMKVY trainees. Below one can find the classification of graduates among the two category types of training. FIGURE 4.

CLASSIFICATION OF RESPONDENT TRAINEES 


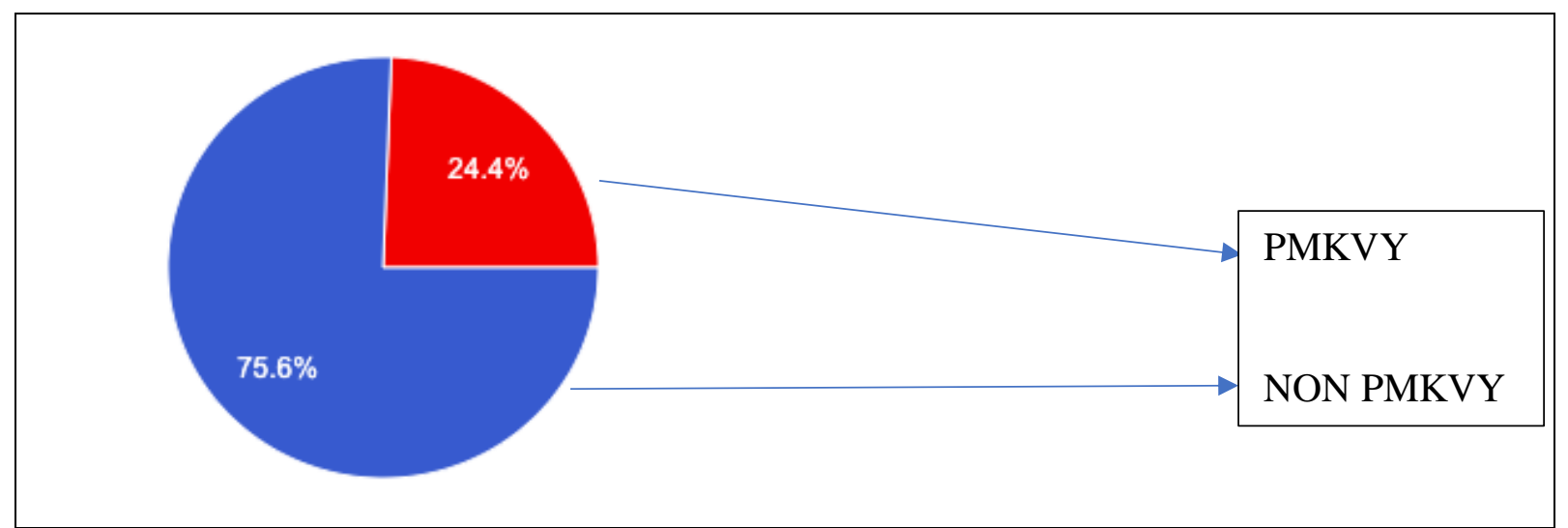

(Source: Own analysis based on web survey)

This sample size brought us wide insights on the extent of employability of these IT/ITeS training programs, where more than $41 \%$ of beneficiaries found themselves employed in Corporate jobs. It was however an anomaly to note that close to the same percentage could not find themselves a suitable job. This leads us to dig further into where the roots of the skilling problem in IT/ITeS sector lies and what steps would help ensure speedier remedy to overt the situation.

FIGURE 5.

CURRENT EMPLOYMENT STATUS OF GRADUATES (PMKVY \& NON PMKVY)

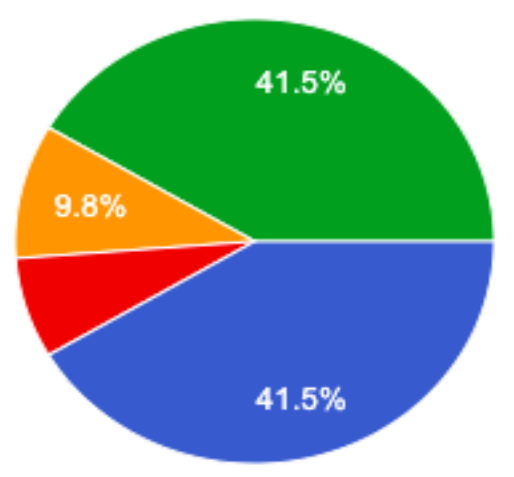

Private Sector

Public Sector

Own Business

Not Employeed

FIGURE 6.

HOW MUCH OF THE SKILLS TAUGHT IN PMKVY \& NON PMKVY TRAINING CENTRES HAS ENABLED EMPLOYMENT IN IT/ITES SECTOR 


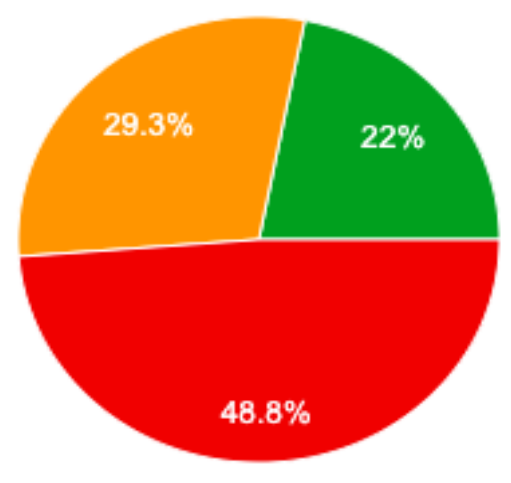

Based on their perception on the value add obtained from these trainings (in terms of new jobs, better employment) a skills rating board was created. This would help arrive at a score of Propensity for upskilling. This could serve as a parameter on deciding the kind of skillsets that needed more attention and would rank in for more governmental investment.

A second survey on 150 Training Institutions(trainers) in the IT/ITeS sector in India was undertaken as to the type of skill sets provided to their trainees. On interviewing them, a list of 25 skillsets were collated and their perception on grading of skills based on significance to employability was taken up. The analysis helped segment IT skills into 4 major quadrants. These were - PROTECT, ACCOMMODATE, EMERGE and IMPROVE quadrants.

The set of 25 significant IT/ITeS skills were sought to be rated by these 150 trainers on a 9-point scale of horizontal and vertical attributes for each of the skills. While the Horizontal traits enumerated for ranking were

\begin{tabular}{|lc|}
\hline & Horizontal Attribute \\
$5=$ & Conventional IT skills \\
$9=$ & Equal mix of both \\
& Analytics \& Applicability to \\
\hline
\end{tabular}

These skillsets were put for rating also based on those Vertical attributes as below:

\begin{tabular}{|cc|}
\hline & Vertical Attribute \\
$1=$ & Lower Future Value of Cost \\
$5=$ & Equal mix of both \\
$9=$ & Higher Future Value of Cost \\
\hline
\end{tabular}

The analysis facilitated an additional advantage of exploring possible permutations and combinations that would encourage and promote skilling, reskilling and upskilling among youth. In other words, advance the propensity to upskilling among IT skilled workforce in the country.
Mapping of the entire IT skills ecosystem in India (including the Skill India movement initiatives) into the above mentioned four quadrants brought forth valid insights for: 
Evaluating the existing structure of skill development network since inception of the new framework of 2015 Suggesting improvements to better cater to obtainment of program objectives

Effectively equipping our resources to meet the demands of changing market conditions

FIGURE 7.
The figure below is a Perceptual map of Propensity to upskill in IT/ITeS skills, which has been drawn encompassing a number of factors (from interviews taken on a sample of 150 Skill Training institutions in India). Similar to the BCG matrix, the two critical inputs to align to IT/ITeS Skills Ecosystem in India that have been factored into are: Skill type and Future value of cost.

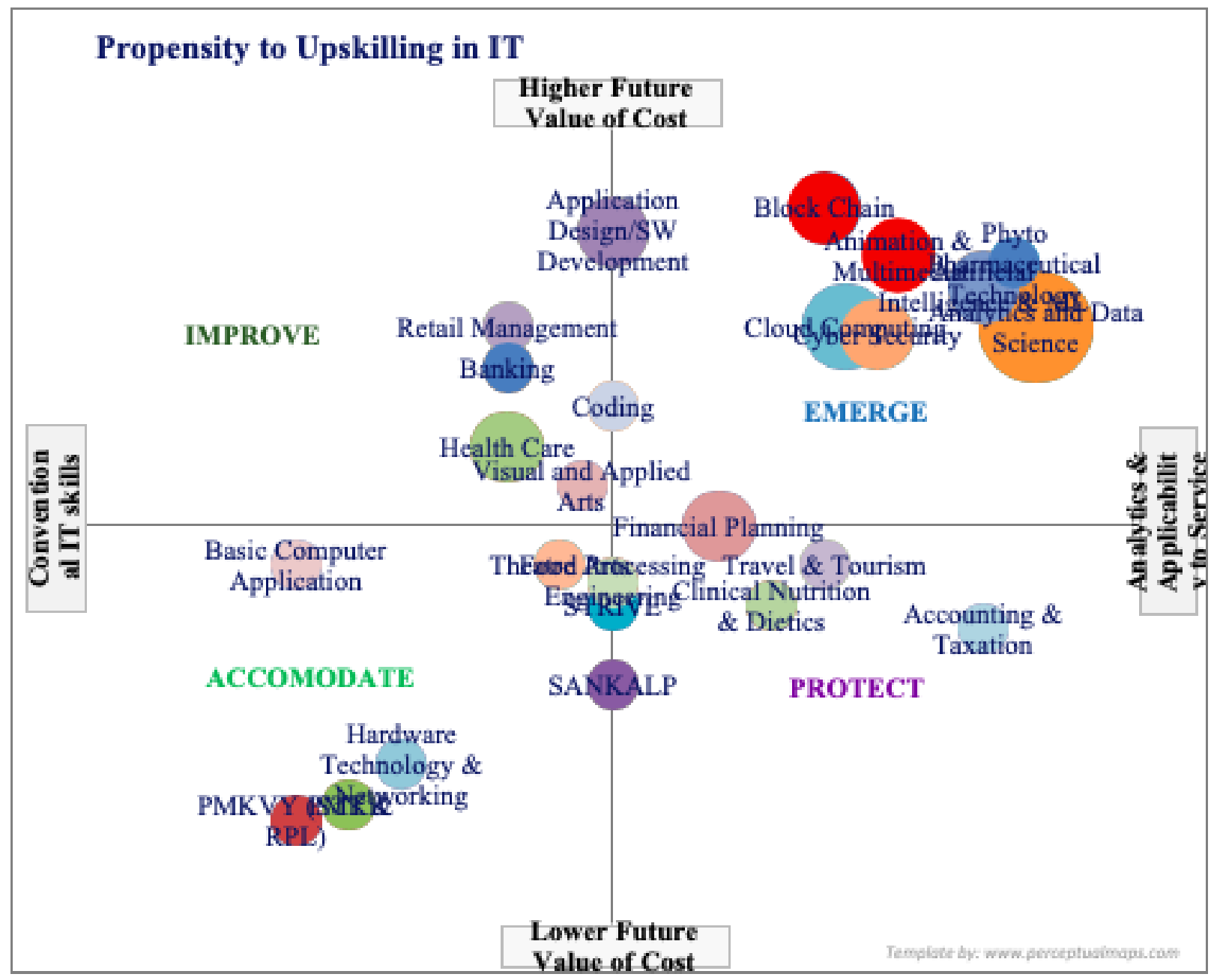

\section{DATA INTERPRETATION AND ANALYSIS}

The results proved that close to $20 \%$ of the trainees who were PMKVY skilled, were found to be unemployed, some of them (5-7\%) set up their own businesses.

Considering, the extent to which the skills training was useful for getting jobs, PMKVY responses did not look that encouraging - while $4.2 \%$ were employed with the Public sector, many of them were not eligible to apply for jobs in the Private sector. This was owing to their lower academic background. Most of them were Diploma holders and not graduates. However, NON

(Source: Prepared by Self)

PMKVY trainees showed better employability potential. More than $40 \%$ of them were employed immediately at private companies, based on their skills cum academic background. This leads us to reject the null hypothesis 1 , which stated that IT/ITeS training programs under Skill India movement do not help in bridging the gap in employability in India. An analysis of the Qualification of candidates who had enrolled in PMKVY programs could give us a quick insight as to why many of the skilled candidates could not find suitable jobs.

\begin{tabular}{|l|l|l|l|l|l|c|}
\hline $\begin{array}{l}\text { Enrolled } \\
\text { Respondents }\end{array}$ & $\begin{array}{l}\text { 9th to } \\
\text { 10th }\end{array}$ & ITI & 11th to 12th & Diploma & Graduate & $\begin{array}{c}\text { Post } \\
\text { graduate }\end{array}$ \\
\hline
\end{tabular}




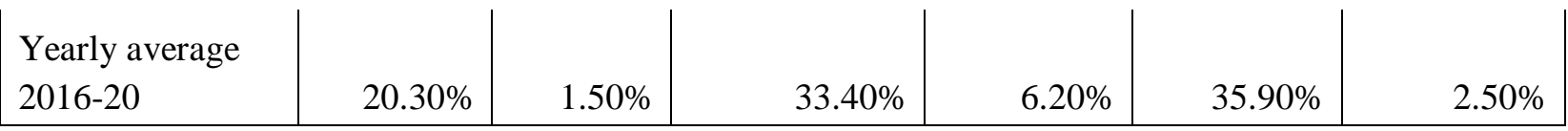

(Source: NSDC PMKVY Enrollments 2015-20)

With most of the job roles in IT/ITeS category requiring prospective employees to be Graduates and Postgraduates, many of these trainees find themselves misfits to the demand in market. This would need to be urgently addressed - Be it the lack of acceptance for the skills provided by the Informal Stream, or missing link connecting the Formal and Informal streams of Skilling in the country.

Skills sets like Data Science and Analytics, Cloud Computing, Cyber Security, Phyto Pharmaceutical technology and AI were found to have higher acceptance among the youth today. These were the skillsets offered in NON funded or NON PMKVY training centers. Most of the PMKVY courses were oriented towards conventional skills like Data Entry, Basic programming, Customer Support (Voice \& NonVoice) etc, thereby calling for scaling up skill sets towards Data Science, Analytics and the like.

IT/ITeS skills in demand were offered mostly by those NON PMKVY institutions, which helped these trainees to secure jobs earlier than the rest (1-4months after their training).

These derivations lead us to reject the null hypothesis on Hypothesis 2 that tested there is no difference in the effectiveness of the various skill training programs under Skill India movement (PMKVY and Non PMKVY). Thus, there essentially is a difference in effectiveness towards employability generation among the different programs taught under Skill India movement.

A common thread running through both of these training types was that awareness among the population regarding these alternate skill training types was much restricted.

\section{RESULTS AND DISCUSSION}

Our Analysis and interpretation proved to a great extend the effectiveness in implementation and future prospects for developing courses in the line of the NON PMKVY type. However, they were also fret with their share of challenges and issues.
Teething problems or challenges impacting these new courses:

- These programs are usually offered on campus and their reach available to only a few students.

- Lack of awareness of these programs and nonavailability of online programs has constituted a major setback to the effectiveness and goals of the Skill India movement.

- On the other hand, we find the mushrooming of Private Training institutes offering Online training programs at costs often unaffordable to common man. Many of these institutions offer not just course work but also training in resume preparation for novice students, offer live projects and Industry experience, Interview preparation and company connect.

- Many of the courses offered by Academic colleges today are currently temporarily closed due to lack of infrastructural support for Online education.

\section{IMPLICATIONS OF THE RESEARCH}

The need for increased governmental support to the NON PMKVY IT/ITeS training courses, more awareness among the public and more integration of academic courses with the skills domain is what this study brings before as suggestions for improvement.

1. Skills sets like Data Science and Analytics, Cloud Computing, Cyber Security, Phyto Pharmaceutical technology classed under 'EMERGE' were proved to be highly disruptive in business continuity and resilience, specific to the Covid-19 impact.

2. Conventional skill sets (those that found themselves under 'ACCOMMODATE' space) though not impactful to the economy, are not to be neglected by any progressive economy.

3. 'PROTECT' category skill sets contributive to steady livelihood through entrepreneurship and impetus to consumer spending were to be protected.

4. Expanded focus on skillsets classified as 'EMERGE', while maintaining courses in 
the 'PROTECT' and 'ACCOMMODATE' quadrant.

5. Inducing more funds into the 'IMPROVE' category of skill sets, as they would need to improvise to facilitate recovery and growth of economy in the future.

6. Increase accessibility to Online IT/ITeS skill development programs.

7. MSDE and NASSCOM to promote the availability of more free online courses in emerging technologies.

8. Enhancing Industry collaboration in course curriculum design to incorporate immediate needs of the market.

9. Promoting more International collaborations or MOU on IT/ITeS skill development and cross border mobility of skilled workforce.

\section{FURTHER SCOPE OF THE STUDY}

If the recommendations provided as part of this paper are adopted, it will help in increasing the employability

\section{REFERENCES}

1. Agrawal (2013). Vocational Education and Training programmes (VET): An Asian perspective. Asia-Pacific Journal of Cooperative Education, 2013, 14(1), 15-26.

2. Bhattacharya (2017). Skilling India's skewed workforce.

3. http://www.dailypioneer.com/columnists/oped/ skilling-indias-skewed-workforce.html

4. Mini Sherino, N M K Bhatta (2020). Disruption to the Skills Ecosystem in India in the wake of the New Normal Post 'COVID-19. AIJR Preprints, 87, version $1,2020$. https://preprints.aijr.org/index.php/ap/preprint /view/87

5. Environment Scan report- KPMG (2016). NSDC.

6. http://www.tsscindia.com $/$ media/2565/kpmgenvironmental-scan-report-2016.pdf

7. Economic Survey (2018-19). https://www.indiabudget.gov.in/economicsurve y/doc/echapter.pdf

8. IT \& ITeS Industry report, IBEF (2019). https://www.ibef.org/archives/industry/indianiT-and-iTeS-industry-analysis-reports/indianiT-and-iTeS-industry-analysis-june-2019 in IT sector, which will not only increase the employment rate in India, but also provide more skilled manpower for the IT sector, which will in a way pave the path for economic recovery and growth in the new normal.

This is essentially the Volte face or new turning that our Skill program implementation agencies (PIAs) under the Ministry of Skills Development and Entrepreneurship needs to proactively imbibe in the wake of the new normal -

(1) Promote IT skills of the right mix (that help in speeding economic recovery),

(2) To encourage collaboration between government, private and industry on curriculum development

(3) Identify newer ways to encourage IT skills training by both - formal and non-formal training institutions

(4) Support and scale up newer models of IT skills training in alignment with the industry for reskilling and upskilling in the country.

9. Khare (2014). Employment, employability and higher education in India: The missing links. Higher Education for the future. Journals.sagepub.com.

10. Karnataka Skills gap report - KPMG IT and ITeS report (2013). National Skills Development CorporationNational Information Technology policy (2012). Government of India.

https://pib.gov.in/newsite/PrintRelease.aspx?r elid $=87875$

11. Mehrotra (2016). NVEQF: Skill Development under the National Skills Qualifications Framework in India: Imperatives and Challenges. Springer Fachmedien Wiesbaden, 2016.

12. Singhal \& Sneader (2020). The future is not what it used to be: Thoughts on the shape of the next normal. McKinsey\& Company. April 2020

13. NASSCOM B2B electronic report (2019). https://www.electronicsb2b.com/headlines/ind ia-facing-shortage-of-skilled-it-workforce-asdemand-for-new-technologies-growsnasscom/ 
14. National Classification of Occupations (2015). Ministry of Labour \& Employment; Government of India

15. National Policy for Skill Development and Entrepreneurship, (2015). www.msde.gov.in , www.skilldevelopment.gov.in

16. National Skill Development Mission: A Framework for Implementation (2015). www.msde.gov.in, www.skilldevelopment.gov.in
17. Annual report MSDE (2017-18). Progressing towards an empowered India.

18. The submitted manuscript is an original work of the author (s) (Mini Sherino and Dr. NMK Bhatta) and has not been submitted to any conference, journal or magazine. The similarity with other available works, if any, is below $15 \%$. 